\title{
On Distributivity and Pluractionality
}

\author{
Lisa Matthewson \\ University of Massachusetts, Amherst
}

\section{Introduction}

In this paper I investigate the semantics of the distributive element pelpála7 in St'át'imcets (Lillooet Salish). An example is given in (1). ${ }^{1}$

$$
\begin{array}{llrll}
\text { cát-an'-as } & \text { s-Laura } & \text { pelpála7 } & \text { i } & \text { xétsem-a } \\
\text { lift-TR-3ERG } & \text { NOM-Laura } & \text { DISTRIB } & \text { DET.PL } & \text { box-DET } \\
\text { 'Laura lifted the boxes distributively.' } & &
\end{array}
$$

In section 2 I present the basic data, and then demonstrate that pelpála7 does not mean the same thing as English each. Unlike each, pelpála7 does not universally quantify over individuals. In section 3 I present my analysis of pelpála7, according to which the sentence in (1) is true if and only if there is an event which is the sum of liftings of individual boxes by Laura. I then show that the analysis enables us to predict under which circumstances the presence of extra, non-distributive liftings will cause speakers to reject the sentence.

In section 4, I show that pelpála7 shares some properties with pluractional markers (Lasersohn 1995, and references therein). Just like temporal pluractional markers, pelpála7 requires there to be a set of subevents which are temporally separated from each other. However, unlike familiar pluractional markers, which operate on VP-denotations, pelpála7 takes both a nominal and a VP argument, and may appear inside DP, in the position occupied by ordinary quantifiers over individuals such as 'all' or 'many'. In section 5 I point out that my analysis of pelpála7 bears some similarity to Zimmermann's (2000a,b) analysis of English adjective/adverb pairs (occasional(ly), sporadic(ally)), whereby the 'adjective' versions really involve pluractional quantifiers (see also Stump 1981, Larson 1998, 1999).

In section 6, I draw attention to the learnability issue raised by cross-linguistic variation in the semantics of distributive elements, and offer some speculations about possible approaches to the learnability question.

In this paper I will be using an event semantics, for concreteness that of Kratzer (1994, in prep.). In this framework, there is neo-Davidsonian association of the external argument but not the internal arguments. VPs are of type $<\mathrm{e},<\mathrm{s}, \mathrm{t}\rangle>$; i.e., they denote (Schönfinkeled) relations between individuals and events ( $\mathrm{s}$ is the type of eventualities). A simple example sentence is given in (2). I will provide some further explanation of the framework when it becomes relevant below; see Kratzer's work for details.

$$
\begin{array}{ll}
{[[\text { Laura lifted the table }]]=} & \lambda \mathrm{e}[\text { lift (the.table) (e) \& agent (Laura) (e)] } \\
\text { After existential closure: } & \exists \mathrm{e}[\text { lift (the.table) (e) \& agent (Laura) (e) }]
\end{array}
$$




\section{Data, and a first try}

\subsection{Basic St'át'imcets}

St'át'imcets is a Northern Interior Salish language spoken in the southwest interior of British Columbia, Canada. It is endangered. There are two dialects, Upper St'át'imcets and Lower St'át'imcets.

There is some freedom of word order; word order variations in example sentences do not affect the semantics. Dialectal variation in lexical items should also be ignored.

It will be relevant to know something about the structure of generalized quantifiers in St'át'imcets. As shown in Matthewson (1998), and illustrated in (3), quantifiers in St'át'imcets always attach to full DPs rather than to NPs.

$$
\begin{aligned}
& \text { [tákem [i } \left.\quad \text { smelhmúlhats-a }]_{\mathrm{DP}}\right] \text { wa7 léxlex } \\
& \text { [all [DET.PL women-DET] ] PROG intelligent }
\end{aligned}
$$

'All the women are intelligent.'

(b) * [tákem [smelhmúlhats $]_{\mathrm{NP}}$ ] wa7 léxlex

[all [women] ] PROG intelligent

'All women are intelligent.'

I have argued elsewhere (Matthewson 1999, 2000) that simple DPs in St'át'imcets are of type e; they denote singular or plural individuals. In quantificational constructions such as (3a), the quantifier quantifies over atomic parts of the plural individual denoted by the DP. (In the discussion below, I will sometimes sloppily say that a plural DP picks out a 'group' or a 'set'; this is shorthand for 'plural individual'.)

\subsection{Basic pelpála7}

The only previous discussion of pelpála7 is by van Eijk (1983, 1987, 1997), who records only the Lower St'át'imcets dialect version, pipála7. van Eijk translates pipála7 as '(to do something) one at a time', and this is indeed its closest English equivalent.

Pelpála7 and pipála7 are formed from the word for 'one', pála7, by reduplication. The words appear in various affixed forms according to whether the relevant individuals are people, animals, round objects, etc. (see also van Eijk 1983, 1997).

Pelpála7 frequently appears in main predicate position, as shown in (4).

$$
\begin{aligned}
& \text { pipápla7 lh-7ulhcw-wít-as } \\
& \text { DISTRIB(HUMAN) when-enter-3PL-3CONJ } \\
& \text { 'They came in one at a time.' } \\
& \text { (They were one at a time when they entered.) }
\end{aligned}
$$

(van Eijk 1983:74)

However, pelpála7 may also attach to DP arguments (something which was not noticed by van Eijk). Examples are given in (5) and (6) of pelpála7 attaching to subject and object DPs respectively. ${ }^{2,3}$

$$
\begin{array}{llllll}
\text { pelpápla7 } & \mathrm{i} & \text { smelhmúlhats-a } & \text { cat-an'-táli } & \text { ti } & \text { tíipvl-a } \\
\text { DISTRIB(HUMAN) } & \text { DET.PL } & \text { woman(PL)-DET } & \text { lift-TR-TOP } & \text { DET } & \text { table-DET }
\end{array}
$$

'The women lifted the table one at a time.' 
(b)

pelpápla7 i sk'wemk'úk'wm'it-a zuc-un'-táli ti k'ét'h-a

DISTRIB(HUM) DET.PL children-DET

move-TR-TOP DET rock-DET

'The children moved the rock one at a time.'

(c) pelpápla7 i sk'wemk'úk'wm'it-a tswaw's-en-táli ti k'ét'h-a

DISTRIB(HUM) DET.PL children-DET weigh-TR-TOP DET rock-DET

'The children weighed the rock one at a time.'

(6a) ts'eq'-n-ás s-Mary [pipála7 i

mash-TR-3ERG NOM-Mary [DISTRIB DET.PL potato-DET]

'Mary mashed the potatoes one at a time.'

(b) cát-an'-as s-Laura [pipála7 i

lift-TR-3ERG NOM-Laura [DISTRIB DET.PL box-DET]

'Laura lifted the boxes one at a time.'

(c) tswáw's-en-as s-Lisa [pipál7-usa7 i áopels-a]

weigh-TR-3ERG NOM-Lisa [DISTRIB-round DET.PL apple-DET]

'Lisa weighed the apples one at a time.'

The position occupied by pelpála7 in (5) and (6), namely DP-adjoined, is one which can only otherwise be occupied by quantifiers (see (3) above; see Demirdache et al. 1994, Matthewson 1998 for discussion). I will return to the implications of this in section 5 below.

\subsection{A first try: pelpála7 $=$ each}

Since pelpála7 can appear inside DPs and seems to have a distributive meaning, one obvious hypothesis would be that it is like English each. If pelpála7 were like each, the lexical entry I would give it would be as in (7).

$$
\begin{aligned}
& {[[\text { pelpála7 }]]=\lambda \mathrm{x} \lambda \mathrm{R}_{<\mathrm{e}, \mathrm{st}>} \lambda \mathrm{e}\left[\mathrm { R } ( \mathrm { x } ) ( \mathrm { e } ) \& \forall \mathrm { y } \left[[\mathrm{y}<\mathrm{x} \& \text { atom }(\mathrm{y})] \rightarrow \exists \mathrm{e}^{\prime}\right.\right.} \\
& \left.\left.\left[\mathrm{e}^{\prime}<\mathrm{e} \& \mathrm{R}(\mathrm{y})\left(\mathrm{e}^{\prime}\right)\right]\right]\right]
\end{aligned}
$$

Unlike traditional analyses of each, (7) makes reference to event structure. In this I follow Tunstall (1998), who argues that to distinguish each from every, we need to look at event structures. (7) is essentially the same as Tunstall's (1998) analysis of each; the main difference is that Tunstall is working in a slightly different version of event semantics. ${ }^{4}$

Let's look at a sentence containing pelpála7 and see what the analysis in (7) predicts. The sentence in (8) will receive the meaning in (9).

$$
\begin{aligned}
& \text { [pelpápla7 i } \quad \text { smelhmúlhats-a] cat-an'-táli ti tíipvl-a } \\
& \text { [DISTRIB(HUMAN) DET.PL woman(PL)-DET] lift-TR-TOP DET table-DET } \\
& \text { 'The women lifted the table one at a time.' }
\end{aligned}
$$

$\exists$ e [agent (the.women) (e) \& lift (the.table) (e) \& $\forall y[[y<$ the.women \& atom $(\mathrm{y})] \rightarrow \exists \mathrm{e}^{\prime}\left[\mathrm{e}^{\prime}<\mathrm{e} \&\right.$ agent $(\mathrm{y})\left(\mathrm{e}^{\prime}\right) \&$ lift (the.table) (e') ]]]

Some further explanation of the framework being used (that of Kratzer in prep.) is necessary at this point. Firstly, VP denotations are minimal, in the following sense: the subformula "lift (the.table) (e)" means that e is an event in which nothing apart from lifting of the table takes place. However, e might have proper subevents in which a lifting of the table takes place. 
The second relevant assumption is that all predicate denotations are cumulative, as illustrated in (10) for the predicate lift and for the thematic role predicate "agent".

(10a) $\forall$ e $\forall e^{\prime} \forall x \forall y$ [lift (x) (e) \& lift (y) (e') $\rightarrow$ lift $\left.(x+y)\left(e+e^{\prime}\right)\right]$

(b) $\forall$ e $\forall \mathrm{e}^{\prime} \forall \mathrm{x} \forall \mathrm{y}$ [agent (x) (e) \& agent (y) (e') $\left.\rightarrow \operatorname{agent}(\mathrm{x}+\mathrm{y})\left(\mathrm{e}+\mathrm{e}^{\prime}\right)\right]$

Due to the cumulativity universal, a formula such as (11) doesn't entail that the women lifted the table collectively. Rather, it means that the women are cumulatively the agent of a (possibly complex) event consisting only of table-lifting(s).

$\exists$ e [agent (the.women) (e) \& lift (the.table) (e)]

Returning to the sentence in (8), its meaning (under the assumption that pelpála 7 means the same as English each) is paraphrasable as in (12):

"There is an event e which consists of one or more liftings of the table, and the women are cumulatively the agent of $e$, and for each atomic individual $y$ who is part of the women, there's a subevent e' of e which is a lifting of the table and whose agent is y."

\subsection{Pelpála7 is unlike each}

Let's see why the analysis of pelpála7 proposed in the previous subsection is incorrect. Consider the data in (13). In $(13 \mathrm{a}, \mathrm{b})$ pelpála7 attaches to object DPs, and (13c) is a subject case.

(13a) Context: There are 4 apples. Lisa weighs 3 out of the 4 , one at a time.

ok tswáw's-en-as s-Lisa [pelpál7-usa7 i áopels-a] weigh-TR-3ERG NOM-Lisa [DISTRIB-round DET.PL apple-DET] 'Lisa weighed the apples one at a time.'

(b) Context: There are 10 boxes.

ok ka cát-s-as-a kw-s Mary [pelpála7 i OOC lift-CAUS-3ERG-OOC DET-NOM Mary [DISTRIB DET.PL box-DET]

t'u7 ay t'u7 kw-s ka tsúkw-s-as-a i tákem-a, but NEG just DET-NOM OOC finish-CAUS-3ERG-OOC DET.PL all-DET

tsukw t'u7 i tsúlhak7-a i ka cát-s-as-a finish just DET.PL seven-DET DET.PL OOC lift-CAUS-3ERG-OOC

'Mary lifted the boxes one at a time, but she didn't finish all of them. She only lifted seven.'

(c) Context: There were four women trying to lift a table. Victoria lifted it by herself, Anne lifted it by herself, and Mary and Elizabeth didn't manage.

ok [pelpála7 i smelhmúlhats-a] cat-an'-táli ta tíipvl-a

[DISTRIB DET.PL woman(PL)-DET] lift-TR-TOP DET table-DET

'The women lifted the table one at a time.' 
(13a-c) show that pelpála7 is unlike English each, which would give rise to falsity in the contexts given. Pelpála7 is also unlike the St'át'imcets distributor over individuals, zí7zeg'. Unlike (13a), (14) requires that Lisa weighed all of the contextually salient apples.

$$
\begin{aligned}
& \text { tswáw's-en-as s-Lisa [zí7zeg' i áopels-a] } \\
& \text { weigh-TR-3ERG NOM-Lisa [each DET.PL apple-DET] } \\
& \text { 'Lisa weighed each of the apples.' }
\end{aligned}
$$

There are two possible sources for the difference between pelpála7 and each. The first is that pelpála7 is not a universal quantifier over individuals. It doesn't require that every individual in the denotation of the DP participate in the action.

The second option is that pelpála7 is a universal distributor like each, but the DP it attaches to does not have to pick out the maximal contextually salient group of individuals. For example, in (13a), where Lisa is allowed to weigh three out of four apples, the sentence could be saying that Lisa weighed each of a group of some of the apples (namely three of them).

I will claim that the first option is correct; pelpála7 does not universally quantify over individuals. However, the second option is very plausible, given other facts about the language. In the next subsection I demonstrate first why the second option is plausible, and then why it is wrong.

\subsection{Plausible but wrong: pelpála7 is like each, but the DP is non-maximal}

The idea that pelpála7 is like each, but the DP is non-maximal, is plausible because the plural DPs to which pelpála7 attaches in the relevant examples are independently known not to have to pick out the (individual corresponding to the) entire contextually salient group of individuals. This is illustrated in (15), which is a noncontradictory discourse.

$$
\begin{aligned}
& \text { q'em'p wi xw7útsin i sk'wemk'úk'wm'it-a wa7 } \\
& \text { ten PL four DET.PL child(PL)-DET PROG } \\
& \text { s-7áts'x-s-tum' } \\
& \text { STAT-see-CAUS-1PL.SUBJ } \\
& \text { 'We are looking after } 14 \text { children.' } \\
& \text { wa7 q'7-áol'men i sk'wemk'úk'wm'it-a; } \\
& \text { PROG eat-want DET.PL child(PL)-DET } \\
& \text { 'DET.PL children are hungry; ... } \\
& \text { cuystwí malh áz'-cit ku s-q'a7 } \\
& \text { let's ADHT buy-APPL DET NOM-eat } \\
& \text {... let's buy some food.' } \\
& \text { cw7it-7úl! cw7ay t'u7 kw-s } \\
& \text { many-too NEG just DET-NOM } \\
& \text { tákem i sk'wemk'úk'wm'it-a wa7 q'7-áol'men } \\
& \text { all DET.PL child(PL)-DET PROG eat-want }
\end{aligned}
$$

'That's too much! Not all the children are hungry.'

The discourse in (15) shows that the DP $i$ sk'wemk'úk'wm'ita does not have to pick out the entire group of 14 children. In Matthewson (2000), I explain this by claiming that plural DPs like $i$ sk'wemk'úk'wm'ita have the option of being existentially interpreted. The second sentence in (15) therefore means "There is some 
plural individual composed of children, such that the atomic parts of that individual are hungry." This explains why the DP does not have to pick out the maximal group of $14 .^{5}$

Given these facts, a potential analysis of the pelpála7 sentence in (8) would be that it is true if and only if there is some group of women (a possibly proper subset of the contextually salient women), such that for each of those women, there is a subevent of her lifting the table.

However, this analysis is incorrect. The reason why it is incorrect is that there are ways of forcing the DP to pick out the maximal contextually salient set of individuals. In these cases, pelpála7 still does not force all the individuals to participate.

The crucial cases involve plural demonstrative DPs. As can be seen in (16), DPs containing plural demonstratives necessarily pick out the maximal contextually salient set of individuals. (The symbol \# indicates a grammatical sentence which is infelicitous in the discourse context described.)

(16) Context: There are four children sitting on the sofa.

wa7 tayt [iz' i sk'wemk'úk'm'it-a]

PROG hungry [these DET.PL children-DET]

'These children are hungry.'

(Addressee goes to get food.)

\# cw7it-7úl! cw7ay t'u7 kw-s

many-too NEG just DET-NOM

tákem i sk'wemk'úk'wm'it-a wa7 tayt

all DET.PL child(PL)-DET PROG hungry

'That's too much! Not all the children are hungry.'

Consultant's response: "You said all of them! Did you lie?"

Now consider the minimal triplets in (17) and (18). The (a) sentences show once again that a plain demonstrative cannot be used in a context where not all the contextually salient individuals take part. The (b) sentences show that tákem iz' 'all these' is similarly bad. The (c) sentences show that pelpála7 iz' is acceptable in these contexts.

(17) Context: There are four women in the room. Three of them lifted the table, one by one.

(a) \# cat-an'-ítas [iz' $\quad$ i $\quad$ syeqyáqts7-a] $]$ ti tíipvl-a lift-TR-3PL.ERG [these DET.PL woman(PL)-DET] DET table-DET 'These women lifted the table.'

(b) \# [tákem iz' i syeqyáqts7-a] cat-an'-táli ti tíipvl-a [all these DET.PL woman(PL)-DET] lift-TR-TOP DET table-DET 'All of these women lifted the table.'

(c) ok [pipála7 iz' i cat-an'-táli ti tíipvl-a [DISTRIB these DET.PL woman(PL)-DET] lift-TR-TOP DET table-DET 'These women lifted the table one at a time.' 
(18) Context: There are four boxes in the room. Rose lifts three of them, one at a time.

(a) \# cát-an'-as s-Rose [iz' i $\quad$ xétsem-a]

lift-TR-3ERG NOM-Rose [these DET.PL box-DET]

'Rose lifted these boxes.'

(b) \# cát-an'-as s-Rose [tákem iz' i $\quad$ xétsem-a]

lift-TR-3ERG NOM-Rose [all these DET.PL box-DET]

'Rose lifted all of these boxes.'

(c) ok cát-an'-as s-Rose [pipála7 iz' i $\quad$ xétsem-a]

lift-TR-3ERG NOM-Rose [DISTRIB these DET.PL box-DET]

'Rose lifted these boxes one at a time.'

In summary, we have seen that a demonstrative DP has to pick out all the contextually salient individuals, but when pelpála7 is added to a demonstrative DP, not all of the contextually salient individuals have to participate in the action. This is evidence that pelpála7 does not universally quantify over individuals. It does not mean "for each atomic $x$, there's a subevent e ...".

\section{Analysis}

Our familiar sentence is repeated once more in (19).
[pelpápla7
i
smelhmúlhats-
] cat-an'-táli ti tíipvl-a
[DISTRIB(HUMAN) DET.PL woman(PL)-DET] lift-TR-TOP DET table-DET
'The women lifted the table one at a time.'

The idea of the analysis is that (19) requires there to be an event which consists only of liftings of the table by atomic parts of the group of women picked out by the DP. The lexical entry which achieves this is given in (20), and the meaning for the whole sentence is given in (21).

$$
\begin{aligned}
& {[[\text { pelpála7 }]]=\lambda \mathrm{x} \lambda \mathrm{R}_{<\mathrm{e}, \mathrm{st}>} \lambda \mathrm{e}^{\prime}\left[\exists \mathrm { e } _ { 1 } \ldots \exists \mathrm { e } _ { \mathrm { n } } \left[\mathrm{e}^{\prime}=\mathrm{e}_{1}+\ldots+\mathrm{e}_{\mathrm{n}} \& \forall \mathrm{e}_{\mathrm{n}} \exists \mathrm{y}\right.\right.} \\
& \left.\left.\left[\mathrm{y}<\mathrm{x} \& \text { atom }(\mathrm{y}) \& \mathrm{R}(\mathrm{y})\left(\mathrm{e}_{\mathrm{n}}\right)\right]\right]\right]
\end{aligned}
$$

(21a) $\exists e^{\prime} \exists e_{1} \ldots \exists e_{n}\left[e^{\prime}=e_{1}+\ldots+e_{n} \& \forall e_{n} \exists y[y<\right.$ the.women \& atom (y) \& agent $(y)\left(e_{n}\right) \&$ lift (the.table) $\left.\left.\left(e_{n}\right)\right]\right]$

(b) 'There is an event e' which is the sum of subevents $e_{1} \ldots e_{n}$, and for all $e_{n}$, $e_{n}$ is a lifting of the table and there is an atomic part of the women who is the agent of $e_{n}$."

\subsection{Dealing with non-distributive liftings}

The analysis just given says that sentence (19) will be true if and only if there is an event e' which is the sum of liftings by individual women. The event e' cannot contain any collective liftings. However, the analysis doesn't rule out nondistributive liftings having taken place outside e'. Therefore, one can legitimately ask what kinds of scenarios the analysis rules out. In this subsection I will first outline the facts about non-distributive liftings, and then indicate how the analysis correctly derives these facts. 
When the context given to the consultants contains both distributive and nondistributive liftings, pelpála7 is rejected. This is shown in (22) for both subject and object-attached pelpála7.

(22a) Context: There were four women. Victoria lifted the table by herself, Anne lifted it by herself, and Mary and Elizabeth lifted it together.

$\begin{array}{rlllll}\text { \#[pelpála7 } & \text { i } & \text { smelhmúlhats-a] } & \text { cat-an'-táli } & \text { ta } & \text { tíipvl-a } \\ \text { [DISTRIB } & \text { DET.PL } & \text { woman(PL)-DET] } & \text { lift-TR-TOP } & \text { DET } & \text { table-DET }\end{array}$

'The women lifted the table one at a time.'

(b) ka cát-s-as-a kw-s Vicky [pelpála7 i xétsem'-a]... OOC lift-CAUS-3ERG-OOC DET-NOM Vicky [DISTRIB DET.PLbox-DET] 'Vicky lifted the boxes one at a time ...'

$\begin{array}{ccccccc}\text { \# texw } & \text { t'u7 } & \text { ti7 } & \text { gélgel, nilh t'u7 } & \text { s-ka } & \text { cát-s-as-a } \\ \text { very } & \text { just } & \text { DEMON strong } & \text { FOC just NOM-OOC lift-CAUS-3ERG-OOC } \\ & \text { i } & \text { áw't-a } & \text { án'was } & \text { xétsem' t'qwaw's } \\ & & \text { DET.PL last-DET } & \text { two } & \text { box } & \text { together }\end{array}$
'She's very strong, so she lifted the last two together.'

Speakers often correct such cases by adding an overt description of the nondistributive actions, as shown in (23) and (24).

(23) Context: There are four women participating in a table-lifting competition. The competition consists of liftings by the following women: Mary, then Gertie, then Laura, then Darla, then Laura and Darla together.

$\begin{array}{clllll}\text { \# cat-an'-ítas ti } & \text { tíipvl-a } & \text { [pelpála7 } & \text { i } & \text { smelhmúlhats-a] } \\ \text { lift-TR-3PL.ERG DET } & \text { table-DET } & \text { [DISTRIB } & \text { DET.PL } & \text { woman(PL)-DET] }\end{array}$

'The women lifted the table one at a time.'

Corrected by adding:

nilh-s cat-an'-ítas t'qw'aw's s-Laura wi s-Darla FOC-NOM lift-TR-3PL.ERG together NOM-Laura 3PL NOM-Darla 'And then Laura and Darla lifted it together.'

(24) Context: Laura is in a box-lifting competition. In the competition, she lifts box 1 , then box 2 , then box 3 , then box 4 , then 3 and 4 together.

[pelpála7 i xétsem-a] cát-an'-as s-Laura [DISTRIB DET.PL box-DET] lift-TR-3ERG NOM-Laura 'Laura lifted the boxes one at a time.'

Consultant prefers to add:

nilh aylh s-7án'was-ts xétsem i cat-an'-ás-a FOC then NOM-two-3SG.POSS box DET.PL lift-TR-3ERG-DET

'And then she lifted two boxes.'

Interestingly, pelpála7 sentences become fine if it is made explicit that the non-distributive liftings are not part of the same event as the distributive liftings. This is illustrated in (25) and (26). 
(25) Context: There are four women participating in a table-lifting competition. The competition consists of liftings by the following women: Mary, Rose, Laura. Then after the table-lifting competition has finished, Laura and Darla lift it together for fun.

ok cat-an'-ítas [pipála7 i syeqyáqts7-a] ti tíipvl-a

lift-TR-3PL.ERG [DISTRIB DET.PL woman(PL)-DET] DET table-DET

'The women lifted the table one at a time.'

Consultant's comment: "If they didn't join the contest, then it would be okay, but if they did then it wouldn't be okay."

(26) Laura is in a box-lifting competition. In the competition, she lifts box 1 , then box 2 , then box 3 . Then after the box-lifting competition has finished, she lifts 3 and 4 together for fun.

ok cát-an'-as s-Laura [pipála7 i $\quad$ xétsem-a]

lift-TR-3ERG NOM- Laura [DISTRIB DET.PL box-DET]

'Laura lifted the boxes one at a time.'

Consultant's comment: "Yeah, because I did it consecutive and then it was the end of the contest before I lifted the others."

The generalizations about non-distributive liftings may be summarized as follows. An unstructured context which combines distributive and non-distributive actions lead to rejection of a pelpála7 sentence. A structured context which separates distributive from non-distributive actions leads to acceptance. And an unstructured context which combines distributive and non-distributive actions leads to acceptance of a sentence of the form ' $p$ and then $q$ ' (i.e., the speakers overtly impose a structure.)

What seems to be going on is as follows. For a pelpála7 sentence to be accepted, there has to be a salient event which has the required property of total distributivity. The unstructured contexts fail to meet this requirement. I can see two different reasons why this might be the case.

The first reason could be that principles for the individuation of events force speakers to consider the maximal salient event. If this event contains non-distributive liftings, then there is no salient event in the context which satisfies the distributivity requirement. Therefore, the sentence is false. Once we explicitly separate the nondistributive liftings into a separate event (e.g. by the end of the table-lifting competition), the sentence becomes true.

Alternatively, maybe the rejected sentences are not false, they are simply a very poor way to describe what happened. They give an arbitrarily selective description of a complicated scenario. In (25) and (26), there is a reason to find the purely distributive part more relevant or interesting than the non-distributive liftings, so the sentence becomes good.

This second solution is supported by the data in (23-24). If ' $p$ and then $q$ ' is true, that entails that ' $p$ ' (the original pelpála7 sentence) was true. It was just a very strange way to describe a context which combines both distributive and nondistributive liftings.

Summarizing this subsection, we predict that pelpála7 sentences will be accepted only if there is a salient event consisting only of distributive actions, which is (a) separated from any non-distributive actions by a clear event boundary, and/or (b) perceptually prominent (interesting, relevant). 


\section{Pelpála7's similarity to pluractional markers}

In this section I will compare pelpála7 to pluractional markers as discussed by Lasersohn (1995), among others. We will see that pelpála7 shares some core properties with temporal pluractional markers. However, unlike familiar pluractional markers, pelpála7 does not simply operate on a VP, but takes both a nominal and a verbal argument. In later subsections I will discuss the consequences of this fact for leamability and for similar constructions in English. (Readers are referred to Bar-el 1998 for another discussion of pluractionality in Salish.)

\subsection{Properties of pluractional markers}

Pluractional markers are normally affixes on verbs; they often involve reduplication. They indicate a broad range of "distributive" notions. The most important types are 'action by more than one individual, temporally iterated action, and spatially scattered action' (Lasersohn 1995:238). Lasersohn's first try at the analysis of pluractional markers is given in (27) ( $\mathrm{X}$ ranges over sets of events).

$$
\mathrm{V}-\mathrm{PA}(\mathrm{X}) \Leftrightarrow \forall \mathrm{e} \in \mathrm{X}[\mathrm{V}(\mathrm{e})] \& \operatorname{card}(\mathrm{X}) \geq n
$$

(27) says that a pluractional verb holds true of a group of events if and only if 'its corresponding "singular" verb holds true of each individual event in the group' (Lasersohn 1995:241).

Lasersohn then refines his analysis to account for the three main types of pluractional marker. The subevents must have separate running times (28a), running spaces (28b), or thematic roles (28c). Which is chosen depends on the lexical characteristics of the particular pluractional morpheme.

(28a) temporal pluractionality:

$$
\mathrm{V}-\mathrm{PA}(\mathrm{X}) \Leftrightarrow \forall \mathrm{e}, \mathrm{e}^{\prime} \in \mathrm{X}\left[\mathrm{V}(\mathrm{e}) \& \neg \tau(\mathrm{e}) \text { o } \tau\left(\mathrm{e}^{\prime}\right)\right] \& \operatorname{card}(\mathrm{X}) \geq n
$$

(b) spatial pluractionality:

$$
\mathrm{V}-\mathrm{PA}(\mathrm{X}) \Leftrightarrow \forall \mathrm{e}, \mathrm{e}^{\prime} \in \mathrm{X}\left[\mathrm{V}(\mathrm{e}) \& \neg \mathrm{K}(\mathrm{e}) \text { o } \mathrm{K}\left(\mathrm{e}^{\prime}\right)\right] \& \operatorname{card}(\mathrm{X}) \geq n
$$

(c) participant pluractionality:

$$
\mathrm{V}-\mathrm{PA}(\mathrm{X}) \Leftrightarrow \forall \mathrm{e}, \mathrm{e}^{\prime} \in \mathrm{X}\left[\mathrm{V}(\mathrm{e}) \& \neg \theta(\mathrm{e}) \text { o } \theta\left(\mathrm{e}^{\prime}\right)\right] \& \operatorname{card}(\mathrm{X}) \geq n
$$

The similarity with pelpála 7 is easy to spot. Pelpála7 also requires there to be a set of subevents, each of which satisfies the simple predicate. In the next subsection I will show that pelpála7 also obeys the non-overlap requirement common to pluractional markers, and in particular the temporal non-overlap requirement.

\subsection{The subevents must be temporally separated}

In preceding sections we have seen that a pelpála7 sentence requires that there be a group of subevents (e.g. of table-liftings by individual women). In this subsection I address the question of what type of separation of the subevents pelpála7 requires. Based on data collection so far, it appears that temporal separation is the strongly preferred option. 
All the cases looked at in previous sections involve temporally separated subevents (such as consecutive liftings of boxes or tables). In (29), on the other hand, the subevents are spatially separated, but occur at the same time. All speakers asked have rejected the pelpála7 sentence in this context.

(29) Context: Some potatoes are lined up on the counter, with space in between them, and a board is pressed on top of them, mashing them all at the same time.

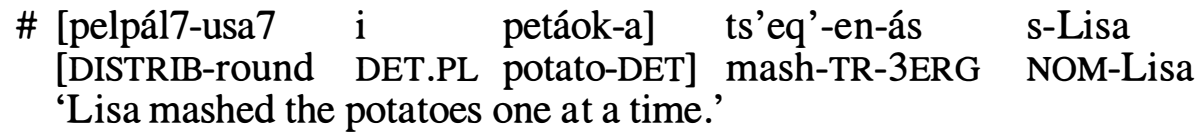

Pelpála7 contrasts in this respect with English each, as noted by Tunstall (1998) (who invented the context in (29)). Tunstall observes that English each does allow spatial separation of the subevents:

(30) Context: Some potatoes are lined up on the counter, with space in between them, and a board is pressed on top of them, mashing them all at the same time.

ok Carol mashed each potato.

(Tunstall 1998:105)

(31) is another example which shows that temporally simultaneous subevents cause pelpála7 to be rejected.

(31) Context: Mary arrives through your front door at the same time as Rose, coming from a completely different place, for a different reason, separately, comes in your back door.

$\begin{array}{llll}\text { \# [pipápla7 } & \text { i } & \text { syeqyáqts7-a] } & \text { t'iq } \\ \text { [DISTRIB(HUMAN) } & \text { DET.PL woman(PL)-DET] } & \text { arrive } \\ \text { 'The women arrived one at a time.' } & \end{array}$

In (32), spatial individuation is marginally sufficient; the sentence is accepted by some speakers and rejected by others. Note that the spatial separation must be overtly mentioned for the sentence to be acceptable by anyone.

$$
\begin{aligned}
& \text { [pipála7 i syeqyáqts7-a] wa7 kúkwpi7 \#(lkw7u tmícw-i-ha) } \\
& \text { [DISTRIB DET.PL woman(PL)-DET] PROG chief } \\
& \text { 'Each of the women is a chief (in her own area).' }
\end{aligned}
$$

Further evidence that pelpála7 is strongly temporal is provided by returning yet again to a comparison with English each. Tunstall (1998) argues that for each, the individuation of the subevents can be temporal or spatial, but there must also be sufficient interest in the differentiation. In fact, the subevents don't have to be separate in either time or space, as long as there is sufficient interest in the individual objects. Some examples are given in (33-34).

(33a) Ricky weighed each apple.

(b) ?\#Ricky took each apple.

(Tunstall 1998:106)

(34a) The cruel girl wounded each cat, but not separately. (Tunstall 1998:108)

(b) ?\#The waitress brought out each drink, but not separately. 
In (33a), it is interesting and relevant that the apples were weighed distributively, rather than together. This contrasts with (33b), where it is probably not very important how Ricky took the apples; what matters is simply the end result that he had all of them. In (34), we can use each cat even if the woundings happened as the result of a single event. This is because individual cats are inherently interesting. On the other hand, we are very unlikely to say (34b), since individual drinks are not inherently interesting.

In contrast to each, pelpála7 does not require any special 'interest' in the differentiation of the subevents. It simply requires temporal individuation. This is illustrated in $(35 \mathrm{a}, \mathrm{b})$, where in each case the felicitous pelpála 7 sentence is compared with a marginal English counterpart using each.

(35a) Context: You invited a bunch of people to a party. You want to explain what happened.

[pelpápla7 i $\quad$ ucwalmícw-a] t'iq

[DISTRIB(HUMAN) DET.PL person-DET] arrive

'The people arrived one at a time.'

?\# 'Each person arrived.'

(b)

[pelpál7-usa7 i áopels-a] kwis lhél-ta tíipvl-a

[DISTRIB- round DET.PL apple-DET] fall from-DET table-DET

'The apples fell off the table one at a time.'

?\# 'Each apple fell off the table.'

In summary, we have seen that pelpála7 is strongly temporal in its requirements. The revised lexical entry required for pelpála7 is given in (36); a clause has been added which stipulates that the running time of the subevents must not overlap (cf. Lasersohn 1995).

$[[$ pelpála7 $]]=\lambda \mathrm{x} \lambda \mathrm{R}<\mathrm{e}, \mathrm{st}>\lambda \mathrm{e}^{\prime}\left[\exists \mathrm{e}_{1} \ldots \exists \mathrm{e}_{\mathrm{n}}\left[\mathrm{e}^{\prime}=\mathrm{e}_{1}+\ldots+\mathrm{e}_{\mathrm{n}} \& \forall \mathrm{e}_{\mathrm{n}} \exists \mathrm{y}\right.\right.$ $\left[\mathrm{y}<\mathrm{x} \&\right.$ atom $\left.\left.\left.(\mathrm{y}) \& \mathrm{R}(\mathrm{y})\left(\mathrm{e}_{\mathrm{n}}\right)\right] \& \forall \mathrm{e}_{\mathrm{n}}, \mathrm{e}_{\mathrm{m}}\left[\neg \tau\left(\mathrm{e}_{\mathrm{n}}\right) \circ \tau\left(\mathrm{e}_{\mathrm{m}}\right)\right]\right]\right]$

The meaning of our familiar sentence under the revised analysis is as paraphrased in (37).

[[ pelpála7 det women lifted the table $]]=$

"There is an event $\mathrm{e}$ ' which is the sum of subevents $e_{1} \ldots e_{n}$, and for all $e_{n}$, $e_{n}$ is a lifting of the table and there is an atomic part of the women who is the agent of $e_{n}$, and for all $e_{n}, e_{m}$, the running times of $e_{n}$ and $e_{m}$ do not overlap."

\section{Similarities with the English occasional construction}

This analysis of pelpála7 presented in this paper displays some similarities with Zimmermann's (2000a,b) analysis of English adjective/adverb pairs such as (occasional(ly), sporadic(ally)). Examples of the 'occasional construction' are given in (38) (see also Bolinger 1967, Stump 1981, and Larson 1998, 1999).

(38a) An occasional sailor strolled by.

= Occasionally, a sailor strolled by. 
(b) A periodic investigation would turn up a few new leads.

= Periodically, an investigation would turn up a few new leads.

(c) The storm was punctuated by a sporadic crash of thunder.

= Sporadically, the storm was punctuated by a crash of thunder.

The adjective versions of each of these pairs raise problems for compositionality, since it is not clear how an element in adjective position can have semantic scope over the whole sentence. Stump, Larson and Zimmermann argue that the supposed 'adjective' combines with the article to create a complex element. According to Zimmermann (2000a,b), the complex [D+A] is a 'pluractional quantifier'; it takes a nominal argument and a VP argument, and specifies that there are some non-overlapping subevent/individual pairs. Zimmermann's analysis of the sentence in (39a) is given in paraphrase form in (39b):

(39a) An occasional sailor strolled by.

(b) There are some pairs $<e, x\rangle$, with e part of a (contextually given) event $\mathrm{e}^{*}$, and $\mathrm{x}$ a sailor, such that $\mathrm{e}$ is a strolling-by of $\mathrm{x}$, and any two strolling-by events of a sailor occur at separate points in time and are performed by different individuals (Zimmermann 2000a).

Zimmermann's analysis of English occasional has much in common with my analysis of St'át'imcets pelpála7. Both occasional and pelpála7 have pluractional properties (the requirement that there be a set of subevents which do not overlap), yet both elements appear DP-internally and take a nominal as well as a VP argument.

The similarity between the two constructions extends even further, when we recall that just like occasional and sporadic, pelpála7 has a non-DP-internal counterpart. As was shown in (4) above, pelpála7 may also appear in predicate position; further illustrations are given in (40).

(40a) pelpála7-wit i smelhmúlhats-a lh-cat-an'-ítas ta tíipvl-a DISTRIB-3PL DET.PL woman(PL)-DET when-lift-TR-3P.ERG DET table-DET 'The women lifted up the table one at a time.'

(The women were separate when they lifted up the table.)

(b) pipál7-usa7 i áopels-a lh-tswáw's-an'-as s-Rick

DISTRIB-roundDET.PL apple-DET when-weigh-TR-3ERG NOM-Rick

'Rick weighed the apples one at a time.'

(The apples were separate when Rick weighed them.)

The predicative use of pelpála7 may in fact be regarded as parallel to an English adverbial usage. In St'át'imcets, adverbials typically appear as main predicates which take subordinate clauses. This is illustrated in (41).
xwem t'u7
kw-en-s
úxwal'
fast just DET.1SG.POSS-NOM
go.home
'I went home quickly.'
(My going home was fast.) 
(b)
xwem-ílc-kan i
i úxwal'-an
fast-body-1SG.SUBJwhen.past go.home-1SG.CONJ
'I went home quickly.'
(I was fast when I went home.)

Therefore, we can say that pelpála7 appears either as an adverb or DPinternally. When it appears DP-internally, it appears in a position (DP-adjoined) which may normally only be occupied by quantifiers (see Demirdache et al. 1994, Matthewson 1998). It thus provides cross-linguistic support for the analysis of 'adjectives' like occasional as being quantificational in their DP-internal usage.

\section{Learnability}

In previous sections we have seen that pelpála7 is a distributive element, which differs from English each. Although pelpála7 is DP-internal, it makes a universal statement about its subevents $\mathrm{e}_{1}+\ldots+\mathrm{e}_{\mathrm{n}}$, rather than about atomic individuals. The question arises of how children are able to learn the subtle differences between the various distributive elements.

The potential for a learnability problem arises because there is no simple mapping between the syntax and the semantics. A simple, and easily learnable, situation would be if DP-internal distributors quantified over individuals, while adverbial distributors quantified over events. However, the pelpála7 data clearly show that this is not the case.

I do not have a conclusive answer to the learnability question, but will make some speculative comments. The first of these has to do with how a St'at'imcetslearner recognizes that pelpála7 has pluractional properties, in spite of being DPinternal. I would like to suggest that this task is relatively easy, because pelpála7 shares a common characteristic with other pluractional elements in the language, namely reduplication.

The data in (42), which are taken from van Eijk (1997:61-65), show that CVC-reduplication is commonly used for pluractional purposes.
a. metscál 'to write'
metsmetscál 'to write a lot'
b. tsí7ig'w 'to bleed'
tsí7ts7ig'w 'to bleed all over'
c. tsíqeq 'to get stabbed'
tseqtsíqeq
d. túpun'
'to punch someone' teptúpun'
'to get stabbed all over'
e. pegwtsám' 'to knock'
f. seqcál 'to split wood'
pegwpegwtsám' 'to knock repeatedly'
seqseqcál 'to keep on splitting w.'

I therefore propose that pelpála7 will be recognizable to a child learner as having pluractional properties due to its reduplication. The precise type of pluractionality (i.e., the fact that the subevents must be temporally separated) will then be learnt however the precise nature of ordinary pluractional markers are learnt. ${ }^{6}, 7$

A second ray of hope for the learnability problem comes from a tentative suggestion by Zimmermann (2000a), to the effect that at a more fine-grained level, there may be a regularity in the syntax/semantics mapping after all. If this is the case, then child learners would have a much easier task. Zimmermann suggests the two stipulations in (43).

(43a) Quantifiers appearing below D (i.e. adjoined to NP) cannot range over events.

(b) Quantifiers in D and below must range over individuals. 
Applied to St'át'imcets, the claims in (43) make the prediction that an element like pelpála7, which makes a universal statements about subevents, may not appear below the $\mathrm{D}^{0}$ level. This is correct. Unlike all other predicates or quantifiers, DPinternal pelpála7 may only appear in DP-adjoined position, and may not appear after the $\mathrm{D}^{0}$. This is shown in (44).

(44a) * cát-an'-as s-Laura [i $\quad$ pelpál7-a $\quad$ xétsem $]$

lift-TR-3ERG NOM-Laura DET.PL DISTRIB-DET box

'Laura lifted the boxes one at a time.'

(b) cát-an'-as s-Laura [i tákem-a xétsem]

lift-TR-3ERG NOM-Laura DET.PL all-DET box

'Laura lifted all the boxes.'

(c) cát-an'-as s-Laura [i cw7ít-a xétsem]

lift-TR-3ERG NOM-Laura DET.PL many-DET box

'Laura lifted many boxes.'

Much further work is necessary before the stipulations in (43) can be verified, let alone explained. Nevertheless, the approach seems to provide an avenue worth exploring.

\section{Conclusions}

In this paper, I have shown that pelpála7 is a distributor which differs from English each in that it does not require every individual in the denotation of its nominal to participate in the action. I have proposed that pelpála 7 requires that there be a salient event which consists only of temporally separated subevents whose participants are atomic individuals.

I have demonstrated how this analysis enables us to predict the circumstances under which speakers will reject pelpála7 sentences in scenarios which contain both distributive and non-distributive actions.

I have further argued that pelpála7 has pluractional properties. Just like temporal pluractional markers, it requires there to be a set of temporally separated subevents. Unlike familiar pluractional markers, however, pelpála 7 may appear not only in predicate / adverbial position, but also in quantifier position. I have claimed that there are similarities between St'át'imcets pelpála7 and the English occasional construction, under an analysis whereby occasional forms part of a complex quantifier with pluractional properties.

Finally, I have pointed out that the observed cross-linguistic variation in types of distributor raises a learnability issue, especially given the lack of an obvious relation between the syntax of a distributor and its semantics (whether it gives rise to a universal statement about subevents or about atomic individuals). I have speculated that the properties of pelpála 7 are learnable by virtue of it involving reduplication, a common way to indicate pluractionality in St'át'imcets.

\section{Endnotes}

* I am very grateful to St'át'imcets consultants Beverley Frank, Gertrude Ned, Laura Thevarge, and Rose Whitley. I am also very grateful to Irene Heim and Angelika Kratzer for lots of valuable feedback and suggestions, and to Henry Davis 
for collecting some of the crucial data as well as for helpful discussions. Thanks also to Ana Arregui, Lyn Frazier, Nancy Hall, Mako Hirotani, Eva Juarros, Ji-yung Kim, Meredith Landman, Marcin Morzycki, Elisabeth Villalta, Adam Werle, Susanne Winkler, and the audience at SALT X. All errors are my own. Fieldwork was supported in part by SSHRCC grant \#410-95-1519.

${ }^{1}$ Data are written in the practical orthography of the language; see van Eijk and Williams (1981). The number 7 represents a glottal stop.

${ }^{2}$ One consultant only allows predicative pelpála7, not DP-internal pelpála7.

${ }^{3}$ The subject cases in (5) could be analyzed either as containing predicative pelpála7, or DP-internal pelpála7. The object cases in (6) unambiguously involve DP-internal pelpála7.

${ }^{4}$ (7) is also essentially identical to Kratzer's (in prep.) analysis of adverbial each / individually. The only difference is that pelpála7 is an adnominal element.

${ }^{5}$ More precisely, the analysis in Matthewson (2000) is that the plural determiner introduces a choice function variable which can be existentially closed. The details of this are not crucial for current purposes.

6 The non-pluractional zí7zeg' 'each' (see example (14)) does not synchronically involve reduplication.

7 This explanation for St'át'imcets obviously does not extend to the English occasional construction, since occasional and the other adjectives do not contain any such clues to pluractionality.

\section{References}

Bar-el, Leora 1998. Verbal Plurality and Adverbial Quantification: A Case Study of Skw $\underline{x}$ umesh (Squamish Salish). MA dissertation, University of British Columbia.

Bolinger, Dwight 1967. Adjectives in English: Attribution and Predication. Lingua 18:1-34.

Demirdache, Hamida, Dwight Gardiner, Peter Jacobs and Lisa Matthewson 1994. The Case for D-quantification in Salish: 'All' in St'át'imcets, Squamish and Secwepemctsín. Papers for the 29th International Conference on Salish and Neighboring Languages, 145-203. Pablo, Montana: Salish Kootenai College.

Kratzer, Angelika 1994. On External Arguments. In Benedicto and Runner (eds.), Functional Projections. UMOP 17, GLSA, University of Massachusetts, Amherst.

Kratzer, Angelika in prep. The Event Argument.

Larson, Richard 1998. Events and Modification in Nominals. Proceedings from SALT VIII, MIT, 145-168.

Larson, Richard 1999. Semantics of Adjectival Modification. Lectures at the LOT Winter School, Amsterdam.

Lasersohn, Peter 1995. Plurality, Conjunction and Events. Dordrecht: Kluwer.

Matthewson, Lisa 1998. Determiner Systems and Quantificational Strategies: Evidence from Salish. The Hague: Holland Academic Graphics.

Matthewson, Lisa 1999. On the Interpretation of Wide-Scope Indefinites. Natural Language Semantics 7:79-134.

Matthewson, Lisa 2000. Quantification and (the Absence of) Cross-linguistic Variation. In Kusumoto and Villalta (eds.). UMOP 21, GLSA, University of Massachusetts, Amherst.

Stump, Gregory 1981. The Interpretation of Frequency Adjectives. Linguistics and Philosophy 4:221-257. 
Tunstall, Susanne 1998. The Interpretation of Quantifiers: Semantics and Processing. Ph.D. dissertation, University of Massachusetts, Amherst.

van Eijk, Jan 1983. A Lillooet-English Dictionary (preliminary edition). Ms., Mount Currie.

van Eijk, Jan 1987. A Lillooet-English Dictionary. Ms., Mount Currie.

van Eijk, Jan 1997. The Lillooet Language: Phonology, Morphology, Syntax. Vancouver: University of British Columbia Press.

van Eijk, Jan and Lorna Williams 1981. Lillooet Legends and Stories. Mount Currie: Ts'zil Publishing House.

Zimmermann, Malte 2000a. Pluractional Quantifiers. Ms., University of Amsterdam / HIL.

Zimmermann, Malte 2000b. The Occasional Sailor Construction in English and German. Paper presented at SALT X, Cornell University. 